\title{
Record of two climber species Ipomoea cairica (L.) Sweet and Ipomoea triloba L. (Convolvulaceae) - new for the flora of Arunachal Pradesh, India
}

\author{
Soyala Kashung, P. R. Gajurel ${ }^{1}$ and B. Singh \\ Department of Forestry, North Eastern Regional Institute of Science and Technology, \\ Nirjuli 791109, Arunachal Pradesh, India \\ ${ }^{1}$ Corresponding author, e-mail: prgajurel@gmail.com
}

[Received 30.11.2018; Revised 15.12.2018; Accepted 17.12.2018; Published 31.12.2018]

\begin{abstract}
Ipomoea cairica (L.) Sweet and Ipomoea triloba L. of the family Convolvulaceae are reported as new records for the state of Arunachal Pradesh in North-eastern India. Both the climbing species are growing along the road side and peripheral zones of forests. Detailed description of these species along with suitable photo-plates are provided here for their easy recognition in the field.
\end{abstract}

Key words: Convolvulaceae, Ipomoea, Arunachal Pradesh, New records, Distribution

\section{INTRODUCTION}

Arunachal Pradesh, the largest northeastern state of India, lies on the easternmost part of Eastern Himalaya. The state by virtue of its geographical position, climatic conditions and altitudinal variations has rich biodiversity. About 5000 species of flowering plants belonging to 1295 genera and 190 families are estimated for the state flora (Dash \& Singh 2017). Among the different habit group of plants dominating the forests, the climbing plants are found common particularly in tropical and sub-tropical vegetation. Among the climbers, the species of Piper, Ipomoea, Dioscorea, Cayratia, Tetrastigma, Thunbergia, Smilax, Stephania, etc. are frequently found in different forests in this area.

The genus Ipomoea L. is one of the large genera of Convolvulaceae and consists of ca. 650 species distributed to different regions of the world (Mabbarley 2008), of which over half of those are distributed mainly in tropical America (Austin \& Huaman 1996). Ipomoea species are mostly annual or perennial herbaceous climbers and rarely shrubs with entire, lobed or divided leaves and showy flowers. The genus is represented by 57 species in India (Hooker 1885). In Arunachal Pradesh occurrence of seven species of the genus viz. Ipomoea alba L., I. aquatica Forssk., I. batatas (L.) Lam., I. mauritiana Jacq., I. nil (L.) Roth, I. purpurea (L.) Roth and I. quamoclit L. have been reported (Chauhan et al. 1996; Srivastava \& Choudhary 2006; Chowdhery et al. 2008; Tag et al. 2009; Doley et al. 2010; Dash \& Singh 2017).

During our study of climbing plant species from the state, we could collect a total of 9 species of Ipomoea of which two species namely Ipomoea cairica and Ipomoea triloba are found as new record for the flora of Arunachal Pradesh. So far, these species are not reported earlier from the state by any worker. Looking at the limited work on the climbing 
342 New record of two spp. of Ipomoea for Arunachal Pradesh
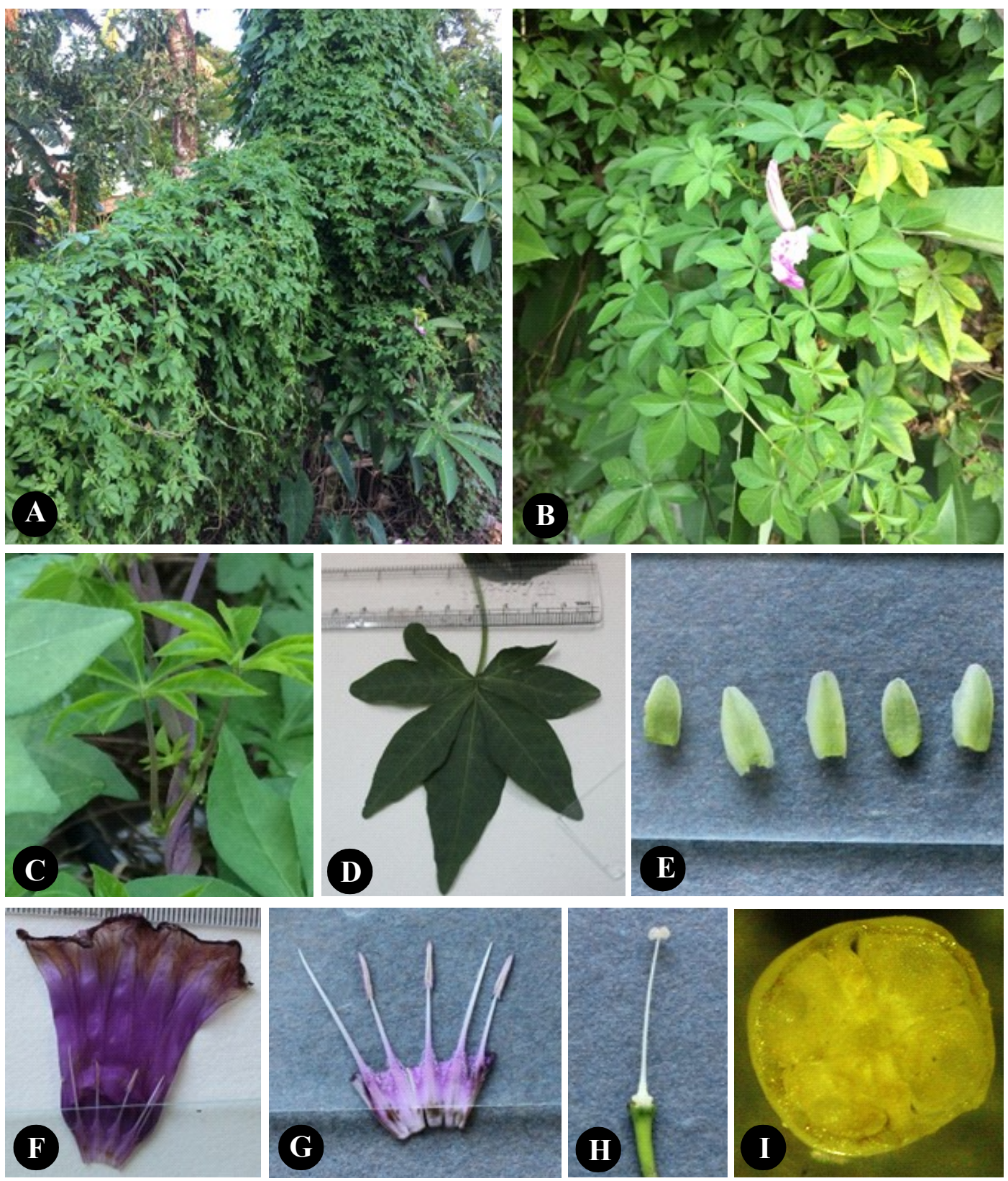

PLATE - I. Ipomoea cairica:A. General habit in natural habitat; B. Close view of plant; C. Anti-clock wise twining of stem; D. Leaf; E. Sepals; F. Corolla splitted; G. Androecium attached to basal part of corolla; H. Pistil; I. T.s. of ovary

flora of the state, the records of the 9 Ipomoea species assume significant in the floristic diversity. Hence, the two additions of the Ipomoea species to the state flora is presented here. The complete description of the two species, including their distribution is provided here along with photographs of the species for easy identification.

Ipomoea cairica (L.) Sweet, Hort. Brit.: 287. 1826; Santapau in Rec. Bot. Surv. India: 16(1): 193. 1953; Ross, Fl. Natal: 295. 1972; Kanjilal et al. Fl. Assam. 3:349. 1984.; Sawmliana, 
The Book of Mizoram Plants (ed. 2). 144. 2013; Devi \& Singh, Res. Journ. Bot. 12(1): 1422. 2017; Convolvulus cairicus L., Syst. Nat. (ed. 10) 2: 922. 1759. Ipomoea palmata Forssk., Fl. Aegypt.-Arab. 43. 1775. Ipomoea stipulacea Jacq., Pl. Rar. Hort. Schoenbr. 2: 39, t. 129. 1797. Ipomoea cavanillesii Roem. \& Schult., Syst. Veg. 4: 214. 1819. Ipomoea heptaphylla Griseb., P1. Wright. 2: 527. 1862. [PLATE - I]

Perennial climber with tuberous roots, twining up to $5 \mathrm{~m}$ or more. Stems slender, slightly angular, smooth. Leaves alternate, $2.5-8 \times 8-9 \mathrm{~cm}$, palmately 5 parted, middle lobe larger, ovate, ovate-lanceolate, or elliptic, entire or slightly undulate, acute or obtuse; petiole $5.5 \mathrm{~cm}$; pseudostipules leafy. Cymes axillary, 1 - several flowered. Flower showy, ca. $4-6$ x $5-8 \mathrm{~cm}$; pedicellate, peduncle $5 \mathrm{~cm}$ long; bracts and bracteoles squamiform and minute. Sepals 5, free, quincuncial; unequal, ovate, obtuse to acute; outer 2 smaller, $0.4-0.6 \mathrm{~cm}$ long; inner three $0.5-0.8 \mathrm{~cm}$ long, glabrous, green with paler margin. Petals 5 , fused, tubular, infundibuliform; corolla tube ca. $1.5-2 \mathrm{~cm}$. dia, lilac with a darker throat. Stamens 5, epipetalous, included, unequal, two longer $2.4-2.6 \mathrm{~cm}$. and three shorter $1.8 \mathrm{~cm}$., filaments pubescent basally. Ovary deltoid or ovate, ca 0.4 x $0.6 \mathrm{~cm}$, carpels 2, 2-loculed, glabrous, imbibed in nectariferous disk; style slender, $2 \mathrm{~cm}$. long, white, glabrous; stigma capitate, 2lobed, papillate. Fruit a capsules (not seen). Capsule brown, 4-valved, with septum dividing into 2 halves. Seeds $0.5-0.6 \mathrm{~cm}$ long, blackish, subglobose, tomentose (Welman et al. 2017).

Flowering: May - June and September - October.

Habitat: Growing on roadsides with ample sunlight, wastelands and fences; in association with Mikania micrantha Kunth, Urena lobata L., Alstonia scholaris (L.) R.Br. and Colocasia sp.

Distribution: India (Andhra Pradesh, Arunachal Pradesh, Assam, Mizoram, Gujarat, Karnataka, Kerala, Maharashtra, Tamil Nadu), Australia, Africa and Tropical Asia, Botswana, Central America, China, South America, Sri Lanka, New Zealand

Exsiccatae: Arunachal Pradesh: Balijan, Soyala 030, 25.06.2017; Arunachal Pradesh: Naharlagun, Soyala 099, 29.09.2018 (Forestry Herbarium, NERIST).

Note: A common species for western and southern India, but rarely reported from north-east India. From north-east it was reported from Assam, Manipur and Mizoram.

Ipomoea triloba L., Sp. P1. 1: 161. 1753. Sourav, Tropical Plant Research 3(1): 102104, 2016; Das, Pleione 11(1): 159 - 162. 2017; Kikon \& Gohain, Indian Journal of Weed Science 49(4): 324 - 328. 2017; Ipomoea blancoii Choisy in DC., Prodr. 9: 389. 1845; Shah, Fl. Gujrat 1: 475. 1978. Ipomoea eustachiana Jacq., Observ. Bot. [Jacquin] pt. 2, 12, t. 36. 1767. Batatas triloba (L.) Choisy, Mém. Soc. Phys. Genève 8(1): 49. 1838. Ipomoea galapagensis Andersson, Kongl. Vetensk. Acad. Handl. 1853: 213. 1855. [PLATE - II]

Annual twining herb growing up to $3 \mathrm{~m}$. Stems slender, terete, glabrous or finely pubescent, sap milky. Leaves alternate, simple; lamina broadly ovate to orbicular, $3-10$ x $3-8 \mathrm{~cm}$, entire or deeply 3-lobed, acuminate-apiculate, base cordate, sparsely pilose; petiole $3-8 \mathrm{~cm}$ long. Cymes aggregated, umbellate, 1 - to several flowered. Flower 1$1.5 \mathrm{~cm}$ long, pedicellate, peduncle $0.4-0.6 \mathrm{~cm}$ long, angular; bracts lanceolate. Sepals 5, slightly unequal, quincuncial, $0.8-0.9 \times 0.3-0.5 \mathrm{~cm}$, sparsely pilose abaxially, margin fimbriate, acute, mucronulate; outer 2 oblong, slightly shorter; inner 3 elliptic-oblong. Petals 5, fused, tubular, infundibuliform, glabrous; corolla tube ca. $0.5 \mathrm{~cm}$ dia., pink or pale purple with a darker throat. Stamens 5, epipetalous, included, unequal, two longer 
344 New record of two spp. of Ipomoea for Arunachal Pradesh
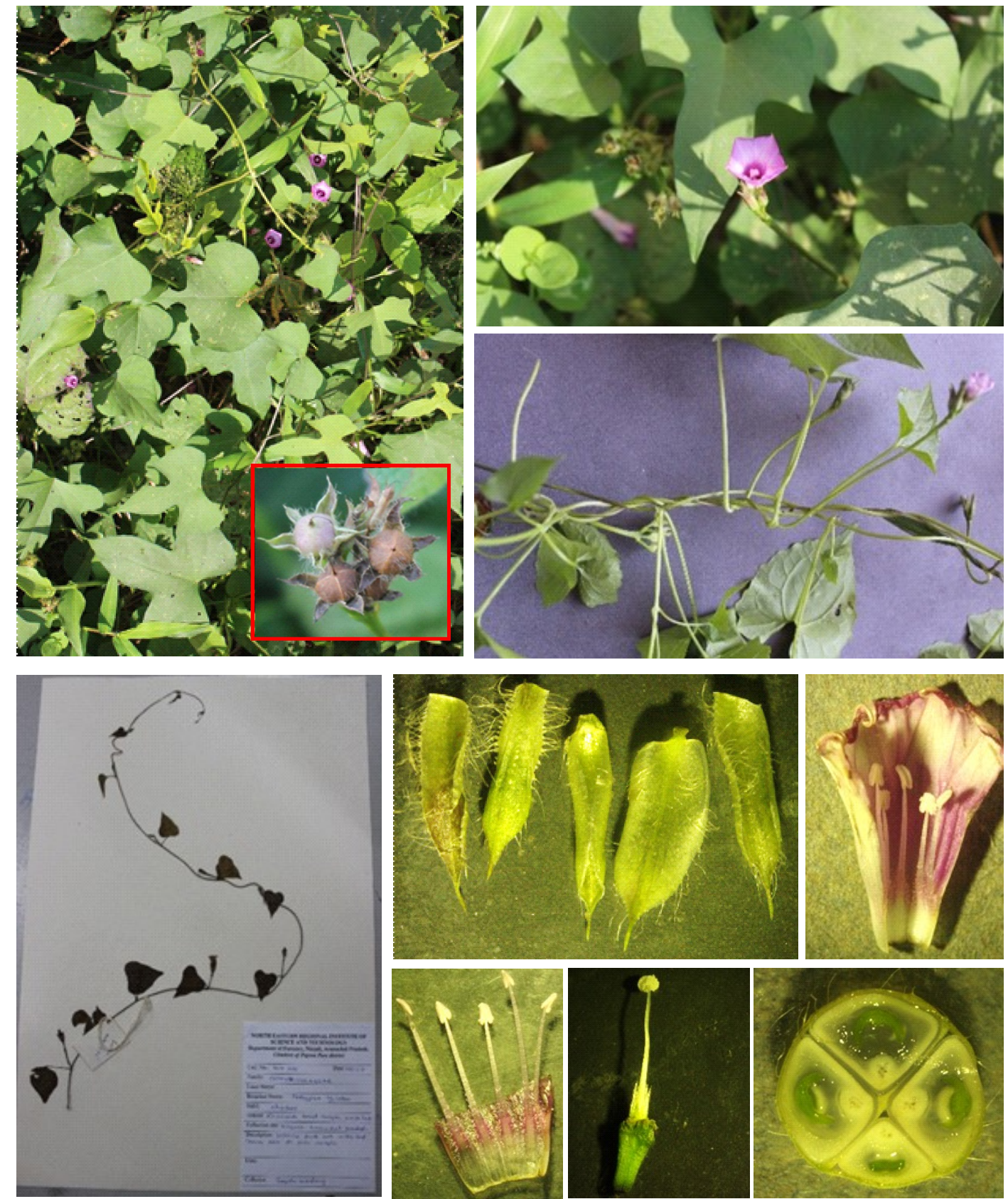

PLATE - II. Ipomoea triloba: J. and K. I. triloba in its habitat; L. Climbing pattern; M. Voucher specimen; N. calyx; O. Corolla; P. Androecium; Q. Pistil; R. T.s. of young fruit (embryos in all four seeds are visible)

$1.1 \mathrm{~cm}$ and three shorter $0.9 \mathrm{~cm}$., filaments pubescent basally. Ovary deltoid or ovate, ca $0.4 \times 0.3 \mathrm{~cm}$, carpels 2, 4-loculed, pubescent, imbibed in nectariferous disk; style slender, 1 $\mathrm{cm}$ long, white, glabrous; stigma capitate, 2-lobed, papillate. Capsules globular, 0.5-0.8 cm dia., apiculate, densely bristly. Seeds generally 4 , dark brown, ca. $0.3-0.4 \mathrm{~cm}$, glabrous, three angled with 2 flat faces and a rounded back. 
Flowering and fruiting: October - January

Habitat: Growing on roadsides, forest margins, disturbed areas, and waste areas; in association with Mikania micrantha Kunth, Chromolaena odorata (L.) R. M. King \& H. Rob., Xanthium strumarium L., Persicaria hydropiper L., Diplazium esculentum (Retz.) Sw. and Gonostegia hirta (Blume ex Hassk.) Miq.

Distribution: India (Arunachal Pradesh, Assam, Chhattisgarh, Delhi, Jharkhand, Jammu \& Kashmir, Karnataka, Kerala, Maharashtra, Tamil Nadu, Uttar Pradesh Uttarakhand), Bangladesh, China, Japan, Malaysia, New Guinea, Philippines, North America, Sri Lanka, Thailand.

Exsiccatae: Arunachal Pradesh, Nirjuli, Soyala 043, 03.11.2017 (Forestry Herbarium, NERIST).

Note: A rare species for north-east and reported earlier only from Assam and Nagaland. In Assam the species was described recently as new record by Das (2017) from Kamrup district only. In Arunachal Pradesh it is rarely distributed unlike other species of Ipomoea. The present record of the species has extended its distribution up to Eastern Himalaya.

\section{LITERATURE CITED}

Austin, D. F. \& Huaman, Z. 1996. A synopsis of Ipomoea (Convolvulaceae) in the Americas. Taxon 45: $3-38$.

Chauhan, A.S; Singh, K.P. \& Singh, D.K. 1996. In: P.K. Hajra (ed.), A contribution to the flora of Namdapha Arunachal Pradesh. Botanical Survey of India, Kolkata.

Chowdhery, H.J.; Giri, G. S.; Pal, G. D.; Pramanik, A. \& Das, S. K. 2008. In: G.S. Giri, A. Pramanik \& H.J. Chowdhery (eds.), Materials for the Flora of Arunachal Pradesh. Vol. 2. Botanical Survey of India, Kolkata.

Das, K.K. 2017. Ipomoea triloba L. (Convolvulaceae): a new record for the flora of Assam, India. Pleione 11(1): 159 - 162.

Dash, S.S. \& Singh, P. (eds.). 2017. Flora of Kurung Kumey District, Arunachal Pradesh. Botanical Survey of India, Kolkata.

Devi, M.H. \& Singh, P.K. 2017. Flowering Calendar of the Macrophytes of Keibul Lamjao National Park, Loktak Lake, Manipur, India. Res. J. Bot. 12(1): 14 - 22.

Doley, B.; Gajurel, P.R.; Rethy, P.; Singh, B. \& Buragohain, R. 2010. Flora of NERIST campus, Arunachal Pradesh, India: a checklist along with their common uses. Pleione 4(1): $8-16$.

Hooker, J. D.1885. The Flora of British India. Vol. IV. L. Reeve \& Co., Ashford, Kent, London.

Kikon, N. \& Gohain, T. 2017. Methods of seeding and cultivars effect on weed dynamics in direct-seeded rice under rainfed upland conditions of Nagaland. Indian J. Weed Sci. 49(4): $324-328$.

Mabberley, D. J. 2008. Mabberley's plant book, A portable dictionary of Plants, their classification and uses. Third Edition. Cambridge University Press, Cambridge.

Sawmliana, M. 2013. The Book of Mizoram Plants. Second Edition. Lois Bet, Aizawl. 
346 New record of two spp. of Ipomoea for Arunachal Pradesh

Sourav, M.S.H. 2016. Ipomoea triloba L. (Convolvulaceae): A new Angiosperm record for the Flora of Bangladesh. Trop. Pl. Res. 3(1): $102-104$.

Srivastava, R.C. \& Choudhary, R.K. 2006. Floristic scenario of Itanagar Wildlife Sanctuary - A case study. Bull. Arunachal For. Res. 22 (1\&2): 17 - 21.

Tag, H.; Das, A.K. \& Saikia, B. 2009. Survey and importance of the flora of Rajib Gandhi University Campus, Rono Hills, Arunachal Pradesh: Checklist - I. Pleione 3(1): 28 - 39.

Welman, W.G.; Herman, P.P.J. \& Condy, G. 2017. Ipomoea cairica (Convolvulaceae). Flowering Plants of Africa 65: 138 - 144. 